\title{
The CDK inhibitors in cancer research and therapy
}

\author{
Jonas Cicenas $\cdot$ Mindaugas Valius
}

Received: 9 June 2011 / Accepted: 12 August 2011 / Published online: 30 August 2011

(C) Springer-Verlag 2011

\begin{abstract}
Chemical compounds that interfere with an enzymatic function of kinases are useful for gaining insight into the complicated biochemical processes in mammalian cells. Cyclin-dependent kinases (CDK) play an essential role in the control of the cell cycle and/or proliferation. These kinases as well as their regulators are frequently deregulated in different human tumors. Aberrations in CDK activity have also been observed in viral infections, Alzheimer's, Parkinson's diseases, ischemia and some proliferative disorders. This led to an intensive search for small-molecule CDK inhibitors not only for research purposes, but also for therapeutic applications. Here, we discuss seventeen CDK inhibitors and their use in cancer research or therapy. This review should help researchers to decide which inhibitor is best suited for the specific purpose of their research. For this purpose, the targets, commercial availability and $\mathrm{IC}_{50}$ values are provided for each inhibitor. The review will also provide an overview of the clinical studies performed with some of these inhibitors.
\end{abstract}

Keywords CDK $\cdot$ Kinases $\cdot$ Small-molecule inhibitors · Cancer $\cdot$ Cell cycle

J. Cicenas $(\bowtie)$

Department of Medicine, Institute of Anatomy,

University of Fribourg, Rte. Albert- Gockel 1,

1700 Fribourg, Switzerland

e-mail: j.cicenas@mapkinases.eu

J. Cicenas

MAP Kinase Resource, Bern, Switzerland

M. Valius

Department of Developmental Biology,

Institute of Biochemistry, Vilnius, Lithuania

\section{Introduction}

Protein kinases are a large family of enzymes catalyzing protein phosphorylation. The phosphorylation results in a change in function of proteins such as their location, interaction with other proteins or enzymatic activity. The human genome contains more than 500 protein kinase genes. Protein phosphorylation plays a central role in the regulation of cell proliferation, differentiation and apoptosis. Therefore, deregulation of kinase activity can result in striking changes in these processes. Particularly, deregulated kinases are often found to be oncogenic and can be central for the survival of cancer cells (Hunter and Cooper 1985). Moreover, the phosphorylation of some proteins, such as ErbB2 (Cicenas et al. 2006; Cicenas 2007; DiGiovanna et al. 2005), EGFR (Cicenas 2007; Kanematsu et al. 2003), Erk (Milde-Langosch et al. 2005; Bergqvist et al. 2006; Svensson et al. 2005), SchA (Cicenas et al. 2010), p21Cip1 (Xia et al. 2004), p27Kip1 (Clarke 2003), Akt (Cicenas et al. 2004, 2005; Cicenas 2008) and retinoblastoma protein ( $\mathrm{Rb})$ (Derenzini et al. 2007), is associated with prognosis in cancers.

Cyclin-dependent kinases (CDKs) are protein kinases involved in important cellular processes, such as cell cycle or transcription regulation. Human genome contains 21 genes encoding CDKs and five genes encoding more distant protein kinases entitled CDK-like (CDKL) kinases. Recently, the new nomenclature for the CDKs had been proposed (Malumbres et al. 2009). The roles of "classical" $11 \mathrm{CDK}$ proteins have been investigated to a different extent. Different CDKs are responsible for the activation of the cell cycle of quiescent cells as well as for the progression of the cell cycle from G1 to mitosis. Each of the CDKs controls a specific checkpoint of the cell cycle. CDKs are activated by the binding to the cyclins and thus forming 
specific complexes. Cdk4-CyclinD, Cdk6-CyclinD and Cdk2-CyclinE complexes regulate the G0-G1 transition and the early phases of G1 through phosphorylation of the $\mathrm{Rb}$. Cdk2-CyclinE complexes are also involved in the G1$\mathrm{S}$ transition. Cdk2 can also associate with CyclinA throughout the progression of $\mathrm{S}$ phase. Cdk1-CyclinA complex participates in the S-G2 and Cdk1-CyclinB G2-M (Malumbres and Barbacid 2005). Cdk3 seems to also participate in $\mathrm{Rb}$ phosphorylation. It is highly related to Cdk2 and Cdk1 and interacts with CyclinE and CyclinA. Cdk5 is activated by $\mathrm{p} 35$ and $\mathrm{p} 39$ proteins that are not cyclins and are typically expressed in brain. Cdk5 mostly acts in neural cells and is involved in the regulation of cell survival, transcription, migration and membrane transport (Dhariwala and Rajadhyaksha 2008). Cdk7 is a component of the Cdkactivating kinase (CAK), which acts upstream of cell-cycle CDKs. It is also a component of the general transcription factor TFIIH and is involved in transcription (Fisher 2005). Cdk8 binds to CyclinC and Cdk9 binds to CyclinT, and they are also involved in the regulation of transcription (Malumbres and Barbacid 2005). No cyclin partner for Cdk10 has been identified so far; however, this kinase seems to be involved in regulating the G2-M phase by inhibition of Ets2 transactivation (Kasten and Giordano 2001). Cdk11 binds to CyclinL and is involved in mRNA splicing (Loyer et al. 2008). It can also interact with CyclinD and repress proliferation (Duan et al. 2010).

Most of the CDKs have been implicated in human cancers. CDK1 had been shown to have a diagnostic value in esophageal (Hansel et al. 2005) and breast cancers (Kim et al. 2008; Nakayama et al. 2009). CDK2 expression or activity has been used for the prognosis of breast (Kim et al. 2008), ovarian (Marone et al. 1998) and oral (Mihara et al. 2001) cancers. Aberrant expression of CDK4 has been implicated in ovarian (Kusume et al. 1999), urinary bladder (Simon et al. 2002), endometrial (Semczuk et al. 2004) and oral (Poomsawat et al. 2010) cancers. CDK5 has been shown to be involved in lung cancer (Choi et al. 2009; Liu et al. 2010). The expression of CDK 6 is also altered in oral cancer (Poomsawat et al. 2010). CDK7 polymorphisms have been shown to have an effect on breast cancer (Jeon et al. 2010).

Aberrations in CDK expression, activity and regulation have also been found in viral infections, neurodegenerative disorders, proliferative diseases, etc. That led to an intensive hunt for small-molecule CDK inhibitors for the therapeutic purposes. All CDK inhibitors developed to date can be subdivided into two main groups: broad-range inhibitors (such as flavopiridol, olomoucine, roscovitine, kenpaullone, SNS-032, AT7519, AG-024322, (S)-Roscovitine and R547) and specific inhibitors (such as fascaplysin, ryuvidine, purvalanol A, NU2058, BML-259, SU 9516, PD 0332991 and P-276-00). The aim of this review is to discuss the properties as well as the use of these inhibitors in cancer research and therapy in more detail.

\section{Broad-range inhibitors}

Flavopiridol (Fig. 1) (also L-868275, HMR-1275, Alvocidib or NSC-649890) is a broad-range CDK inhibitor. It inhibits $\mathrm{CDK} 1, \mathrm{CDK} 2, \mathrm{CDK} 4$ and $\mathrm{CDK} 7$ at $\mathrm{IC}_{50}$ value range of 0.04-0.4 $\mu \mathrm{M}$ (Losiewicz et al. 1994; Carlson et al. 1996). It was first discovered as epidermal growth factor receptor (EGFR) inhibitor, which inhibits at $\mathrm{IC}_{50}$ value of $21 \mu \mathrm{M}$. Later, it was shown that flavopiridol could inhibit the growth of breast and lung cancer cell lines (Kaur et al. 1992) and prostate, head and neck cancer and leukemia xenografts (Drees et al. 1997; Patel et al. 1998; Arguello et al. 1998). Since it did so at much lower concentrations than those needed for the inhibition of the EGFR, new targets were investigated and its effect on CDKs was found.

Flavopiridol is a commercially available inhibitor broadly used in the research. It is also the first CDK inhibitor used in human clinical trials. Several phase I clinical trials showed that flavopiridol as single agent has an antitumor effect in patients with renal, prostate and colon cancer, metastatic gastric cancer and non-Hodgkin's lymphoma (Senderowicz et al. 1998; Tan et al. 2002; Thomas et al. 2002; Whitlock et al. 2005). Secretory diarrhea, neutropenia, nausea, vomiting and proinflammatory syndrome were reported as main drug adverse effects (DAE). Another phase I clinical study of sequential paclitaxel and flavopiridol showed clinical activity in patients with esophagus, lung and prostate cancer including patients who had not

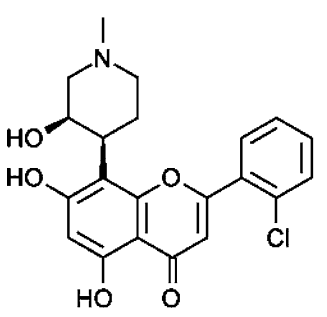<smiles>Cn1cnc2c(NCc3ccccc3)nc(NCCO)nc21</smiles>

Olomoucine

Flavopiridol

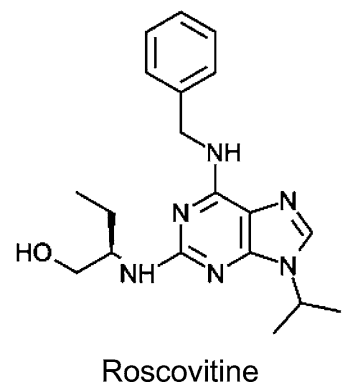

Fig. 1 Flavopiridol, Olomoucine and Roscovitine 
responded to paclitaxel alone (Schwartz et al. 2002). The combination of flavopiridol and docetaxel has been shown to be quite promising in several phase I clinical studies (Fornier et al. 2007; El-Rayes et al. 2006; Tan et al. 2004). The combinations of flavopiridol with gemcitabine and irinotecan (Fekrazad et al. 2010), vorinostat (Dickson et al. 2010), oxaliplatin and fluorouracil/leucovorin (Rathkopf et al. 2009), paclitaxel and carboplatin (George et al. 2008), cisplatin and carboplatin (Bible et al. 2005) and irinotecan (Shah et al. 2005) were also assessed in various solid tumors in phase I clinical trials. In leukemias, flavopiridol both as single agent (Phelps et al. 2009; Blum et al. 2010) and in combinations with 1-beta-D-arabinofuranosylcytosine and mitoxantrone (Karp et al. 2005) and cytosine arabinoside and mitoxantrone (Karp et al. 2011) showed a promise in phase I clinical trials.

Phase II clinical trials involving flavopiridol have also been carried out. Flavopiridol, however, did not have a desired effect in advanced gastric carcinoma (Schwartz et al. 2001), non-small-cell lung cancer (Shapiro et al. 2001), advanced colorectal cancer (Aklilu et al. 2003), androgen-independent prostate cancer (Liu et al. 2004), melanoma (Burdette-Radoux et al. 2004), endometrial carcinoma (Grendys et al. 2005) and advanced soft tissue sarcoma (Morris et al. 2006). It did have a modest effect in mantle cell lymphoma (Kouroukis et al. 2003) and advanced renal cell carcinoma (Van Veldhuizen et al. 2005). Yet in another phase II clinical trial, flavopiridol achieved significant clinical activity in patients with relapsed chronic lymphocytic leukemia (Lin et al. 2009). A phase II study of flavopiridol in combination with docetaxel in pancreatic cancer was also disappointing (Carvajal et al. 2009).

Olomoucine (Fig. 1) is another broad-range $\mathrm{CDK}$ inhibitor. It inhibits CDK1 $\left(\mathrm{IC}_{50}=7 \mu \mathrm{M}\right), \mathrm{CDK} 2\left(\mathrm{IC}_{50}=7 \mu \mathrm{M}\right)$ and CDK5 $\left(\mathrm{IC}_{50}=3 \mu \mathrm{M}\right)$. It can also inhibit ERK1 kinase at higher concentrations $\left(\mathrm{IC}_{50}=25 \mu \mathrm{M}\right)$. Olomoucine is also a commercially available inhibitor and was first purine CDK inhibitor discovered. Olomoucine has never been used in any clinical trials, since the preference was given to its derivative-roscovitine.

Roscovitine (Fig. 1) (also CY-202, (R)-Roscovitine, Seliciclib) is also a broad-range purine inhibitor, which inhibits CDK1, CDK2, CDK5 and CDK7 ( $\left.\mathrm{IC}_{50} \sim 0.5-0.2 \mu \mathrm{M}\right)$ but is a poor inhibitor for $\mathrm{CDK} 4$ and $\mathrm{CDK} 6\left(\mathrm{IC}_{50}>100 \mu \mathrm{M}\right)$. It is also commercially available CDK inhibitor broadly used in the research. Oddly, in a scientific literature, it is frequently referred to as a selective CDK5 inhibitor, despite the fact that it inhibits at least other 3 CDKs. A phase I clinical trial with roscovitine showed no objective tumor responses, but disease stabilization was observed in eight patients (Benson et al. 2007). Main DAEs included fatigue, skin rash, hyponatremia and hypokalemia. Emesis and reversible abnormal liver

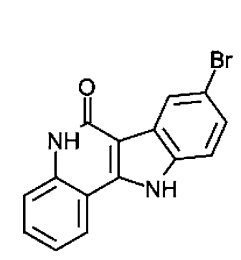

Kenpaullone

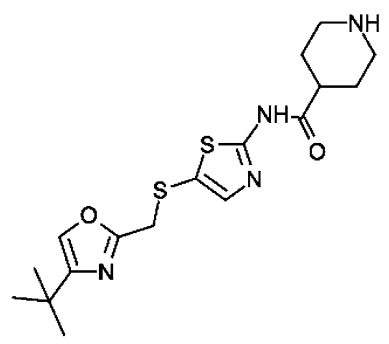

SNS - 032<smiles>O=C(NC1CCNCC1)c1n[nH]cc1NC(=O)c1c(Cl)cccc1Cl</smiles>

AT7519

Fig. 2 Kenpaulollone, SNS-032 and ATZ519

function were also observed. In another phase I clinical trial, one patient with hepatocellular carcinoma showed partial response and six patients achieved tumor (two patients with NSCLC, one with parotid cylindroma, one with corticosurrenaloma, one with thymic carcinoma and one with adenocarcinoma of unknown primary) (Le Tourneau et al. 2010). DAEs included nausea, vomiting, asthenia and hypokalemia. Roscovitine is presently under investigation in several phase II clinical trials in leukemias as monotheraphy and in combination trials against NCLC (with gemcitabine/cisplatin or docetaxel) and metastatic breast cancer (with capecitabine) (Fischer and Gianella-Borradori 2005).

Kenpaullone (Fig. 2) (also NSC 664704, 9-Bromopaullone), another commercially available broad-range $\mathrm{CDK}$ inhibitor, inhibits CDK1 $\left(\mathrm{IC}_{50}=0.4 \mu \mathrm{M}\right), \quad \mathrm{CDK} 2$ $\left(\mathrm{IC}_{50}=0.7 \mu \mathrm{M}\right)$ and CDK5 $\left(\mathrm{IC}_{50}=0.9 \mu \mathrm{M}\right)$. It is much less potent toward CDK4 $\left(\mathrm{IC}_{50}>100 \mu \mathrm{M}\right)$. It also inhibits $\operatorname{GSK} 3 \beta\left(\mathrm{IC}_{50}=0.23 \mu \mathrm{M}\right)$. Kenpaullone was found as an in vitro antiproliferative agent in the NCI's anticancer drug screen panel, and molecular modeling studies have shown that it binds to the ATP-binding pocket of CDK2 similar to other CDK2 inhibitors. Although it is a commercially available inhibitor vastly used in research, it had not entered clinical trials so far.

SNS-032 (also BMS-387032) (Fig. 2) is a broad-range inhibitor, which inhibits CDK9 $\left(\mathrm{IC}_{50}=0.004 \mu \mathrm{M}\right)$, CDK2 $\left(\mathrm{IC}_{50}=0.038 \mu \mathrm{M}\right)$ and $\mathrm{CDK} 7\left(\mathrm{IC}_{50}=0.062 \mu \mathrm{M}\right)$. It can inhibit other CDKs at higher concentration $\left(\mathrm{IC}_{50}>0.3 \mu \mathrm{M}\right)$, but at that concentration, it also inhibits GSK3 kinase. SNS-032 was initially synthesized by Bristol-Myers Squibb Pharmaceutical Research Institute in an attempt to produce a selective inhibitor of CDK2. It was named BMS-387032 at the time. Two phase I clinical trials were carried out for 
metastatic refractory solid tumors and one in lymphoma. All those trials showed that this drug was well tolerated by the patients. Later, already under SNS-032 name, the phase I clinical trial was performed with 21 patients. Patients with metastatic solid tumors or refractory lymphoma were treated with an intravenously administered SNS-032 in a dose-escalation manner. Drug was well tolerated, DAEs being fatigue and nausea. The best clinical response was stable disease in 3 (15\%) patients (Heath et al. 2008). Another phase I trial was performed in 19 patients with advanced chronic lymphocytic leukemia and multiple myeloma (Tong et al. 2010). Major toxicity in that case was myelosuppression. One patient with a chronic lymphocytic leukemia had more than $50 \%$ reduction in measurable disease, and two patients with multiple myeloma had stable disease and one had normalization of spleen size.

$A T 7519$ (Fig. 2) is a broad-range CDK inhibitor, which inhibits CDK1 $\left(\mathrm{IC}_{50}=0.21 \mu \mathrm{M}\right), \mathrm{CDK} 2\left(\mathrm{IC}_{50}=0.047 \mu \mathrm{M}\right)$, CDK4 $\left(\mathrm{IC}_{50}=0.1 \mu \mathrm{M}\right)$, CDK5 $\left(\mathrm{IC}_{50}=0.13 \mu \mathrm{M}\right)$, CDK6 $\left(\mathrm{IC}_{50}=0.17 \mu \mathrm{M}\right)$ and CDK9 $\left(\mathrm{IC}_{50} \leq 0.01 \mu \mathrm{M}\right)$. This compound had lower potency against other CDKs tested (CDK3 and CDK7) and was inactive against all of the nonCDK kinases tested with the exception of GSK3 $\beta$ $\left(\mathrm{IC}_{50}=0.089 \mu \mathrm{M}\right)$. Phase I clinical trial was carried out in 28 patients with refractory solid tumors (Mahadevan et al. 2011). Electrocardiogram showed a dose-dependent increase in QTc. Other adverse effects included fatigue and mucositis. Four patients showed stable disease for more than 6 months and one had an extended partial response. In 2010, Astex Therapeutics and the Multiple Myeloma Research Consortium announced the initiation of a phase II clinical trial of the AT7519 to treat patients with relapsed or refractory multiple myeloma.

$A G-024322$ (Fig. 3) is a broad-range inhibitor, which inhibits CDK1, CDK2 and CDK4 $\left(\mathrm{IC}_{50}=0.1-0.3 \mu \mathrm{M}\right)$. AG-024322 was synthesized by Pfizer Global Research and Development. This inhibitor had been entered into phase I clinical trials, which, however, had been terminated due to the inability of the compound to effectively discriminate from other treatment modalities.

(S)-Roscovitine (Fig. 3) is an inhibitor, which potently inhibits CDK1 $\left(\mathrm{IC}_{50}=0.55 \mu \mathrm{M}\right), \mathrm{CDK} 5\left(\mathrm{IC}_{50}=0.35 \mu \mathrm{M}\right)$ and CDK9 $\left(\mathrm{IC}_{50}=0.9 \mu \mathrm{M}\right)$. It has been neglected as a therapeutical agent in favor of its isomer (R)-Roscovitine, mentioned above.

R547 (also Ro-4584820) (Fig. 3) is an inhibitor selective for CDK1 $\left(\mathrm{IC}_{50}=0.001 \mu \mathrm{M}\right)$, CDK2 $\left(\mathrm{IC}_{50}=0.003 \mu \mathrm{M}\right)$ and CDK4 $\left(\mathrm{IC}_{50}=0.001 \mu \mathrm{M}\right)$. In 2006, Hoffmann-La Roche initiated a phase I study of R547 against locally advanced or metastatic solid tumors; however, results had not been published to date. On the other hand, the expression in patient blood samples of eight genes (FLJ44342, CD86, EGR1, MKI67, CCNB1, JUN, HEXIM1 and

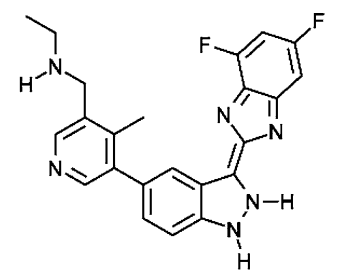

AG-024322

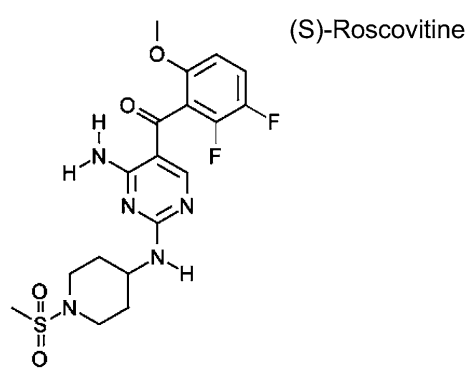

$\mathrm{R} 547$

Fig. 3 AG-024322, (S)-Roscovitine, R547<smiles>Nc1nc(OCC2CCCCC2)c2nc[nH]c2n1</smiles>

NU2058<smiles>CCC(CO)Nc1nc(NCc2ccccc2)c2ncn(C(C)C)c2n1</smiles>

(S)-Roscovitine<smiles></smiles>

Fascaplysin<smiles>Cc1nc2c(s1)C(=O)C=C(Nc1ccc([N+](=O)[O-])cc1)C2=O</smiles>

Ryuvidine

Fig. 4 NU2058, Fascaplysin and Ryuvidine

PFAAP5) was selected as dose-responsive pharmacodynamic parameter for phase II clinical trials (BerkofskyFessler et al. 2009).

\section{Selective inhibitors}

Fascaplysin (Fig. 4) is an inhibitor selective for CDK4 $\left(\mathrm{IC}_{50}=0.35 \mu \mathrm{M}\right)$ and CDK6 $\left(\mathrm{IC}_{50}=3.4 \mu \mathrm{M}\right)$ and not selective for the other CDKs or other kinases. It was originally isolated as a compound showing antimicrobial activity from the sponge Fascaplysinopsis sp. (Roll et al. 1988). It is a commercially available compound, broadly used for the research purposes; however, it has never been entered into clinical trials.

Ryuvidine (Fig. 4) is an inhibitor selective for CDK4 $\left(\mathrm{IC}_{50}=6.0 \mu \mathrm{M}\right)$ and displays $>33$-fold selectivity over 


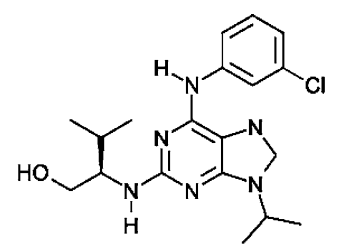

Purvanol A

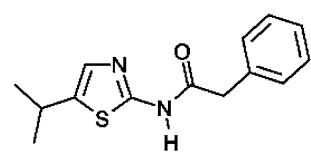

BML-259

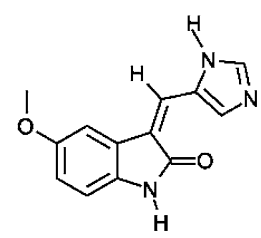

SU 9516
Fig. 5 Purvalanol A, BML-259 and SU 9516

CDK2 (IC50 > $200 \mu \mathrm{M}$ ). Despite the fact that this inhibitor is commercially available, it has not been used widely in the research, nor had it ever entered the clinical trials. However, given its selectivity toward CDK4, as well as cytotoxicity against various cancer cells $\left(\mathrm{IC}_{50}=0.61,1.08,0.30\right.$ and $1.21 \mathrm{mg} / \mathrm{ml}$ against A 549, Col 1, HL-60 and HepG2 tumor cells, respectively) (Ryu et al. 2000), it seems to be quite potent tool for cancer research.

Purvalanol A (Fig. 5) is an inhibitor selective for CDK2 $\left(\mathrm{IC}_{50}=4-70 \mathrm{nM}\right)$ and CDK5 $\left(\mathrm{IC}_{50}=75 \mathrm{nM}\right)$, but less selective toward CDK4 $\left(\mathrm{IC}_{50}=850 \mathrm{nM}\right)$. This inhibitor was identified by combinatorial chemistry approach structure-activity relationship (SAR). It is also a commercially available inhibitor, quite widely used in cancer research (Villerbu et al. 2002). However, purvalanol A has never been entered into clinical trials.

NU2058 (Fig. 4) is an inhibitor selective for CDK2 $\left(\mathrm{IC}_{50}=17 \mu \mathrm{M}\right)$ and $\mathrm{CDK} 1\left(\mathrm{IC}_{50}=26 \mu \mathrm{M}\right)$. NU2058 is a competitive inhibitor that binds in the ATP-binding pocket in a different orientation from other purine-based inhibitors, such as olomoucine and roscovitine (Arris et al. 2000). So far, only preclinical studies had been performed, showing the potential of the compound against several cancer cell lines. This inhibitor had not been entered into clinical trials yet. It is also commercially available.

$B M L-259$ (Fig. 5) is an inhibitor selective for CDK5 $\left(\mathrm{IC}_{50}=64 \mathrm{nM}\right)$ and $\mathrm{CDK} 2\left(\mathrm{IC}_{50}=98 \mathrm{nM}\right)$. It is an ATP competitive CDK inhibitor discovered by molecular modeling studies (Helal et al. 2004). Although it definitely needs further validations and preclinical studies, this compound is already available commercially. So far, no clinical study has been reported for this agent.

$S U 9516$ (Fig. 5) is an inhibitor selective for CDK2 $\left(\mathrm{IC}_{50}=0.022 \mu \mathrm{M}\right)$ and $\mathrm{CDK} 1\left(\mathrm{IC}_{50}=0.04 \mu \mathrm{M}\right)$, but less selective toward CDK4 $\left(\mathrm{IC}_{50} \geq 10 \mu \mathrm{M}\right)$. At higher concentrations, it can also inhibit PKC $\left(\mathrm{IC}_{50} \geq 10 \mu \mathrm{M}\right)$, p38
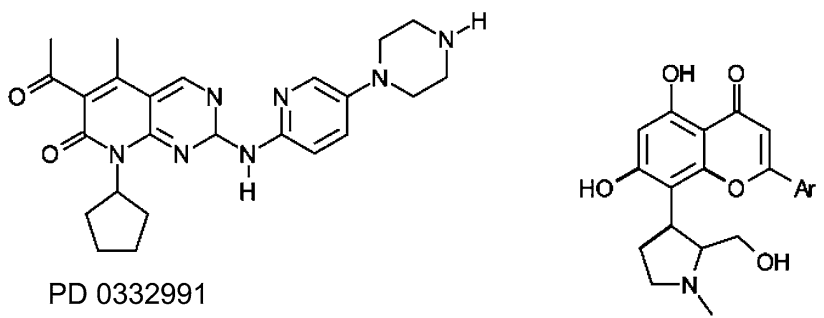

P276-00

Fig. 6 PD 0332991 and P276-00

$\left(\mathrm{IC}_{50} \geq 10 \mu \mathrm{M}\right), \quad$ PDGFR $\quad\left(\mathrm{IC}_{50} \geq 18 \mu \mathrm{M}\right)$ and EGFR $\left(\mathrm{IC}_{50} \geq 100 \mu \mathrm{M}\right)$. It was identified by the means of highthroughput screening with CDK2 and tested on colon cancer cell line in which it decreased cell cycle progression and induced apoptosis (Lane et al. 2001). So far, it has been only tested in preclinical studies.

$P D-0332991$ (Fig. 6) is a highly specific inhibitor of CDK4 $\left(\mathrm{IC}_{50}=0.011 \mu \mathrm{M}\right)$ and CDK6 $\left(\mathrm{IC}_{50}=0.016 \mu \mathrm{M}\right)$, having no activity against a panel of 36 additional protein kinases (Fry et al. 2004). It was an effective antiproliferative agent against retinoblastoma-positive tumor cells, inducing G1 arrest and reducing the phosphorylation of the $\mathrm{Rb}$ protein. Administration of PD-0332991 reduces tumors in mice bearing the Colo-205 human colon carcinoma. Several phase I/II clinical studies with PD 0332991 have been initiated, such as: a study in patients with advanced solid tumors (excluding SCLC and retinoblastoma) or follicular and diffuse large-cell non-Hodgkin's lymphoma, phase I Trial of PD-0332991 plus bortezomib in patients with relapsed mantle cell lymphoma, phase 1 trial of PD0332991 and paclitaxel in patients with Rb-expressing advanced breast cancer, phase II study of PD 0332991 in patients with recurrent $\mathrm{Rb}$ positive glioblastoma; however, the results are not ready yet. Another phase I study of sequential combination of PD-0032991 with bortezomib and dexamethasone had been performed in 21 relapsed and refractory multiple myeloma patients (Niesvizky et al. 2010). The most common treatment-related DAEs were thrombocytopenia and neutropenia. One patient achieved a very good partial response, 1 achieved a partial response, and 3 had stable disease for more than 3 months. Very good partial response was in a patient who had relapsed on lenalidomide, bortezomib and carfilzomib therapies as well as on stem cell transplant. The phase II portion of the trial to evaluate the antitumor activity of PD 0332991 is ongoing. Yet another phase I study of the combination of PD 0332991 and letrozole for first-line treatment of patients with ER-positive, HER2-negative breast cancer had been performed in 12 patients (Slamon et al. 2010). Most common DAEs included neutropenia, leucopenia and fatigue. Three patients had partial response and 9 patients had stable disease. A randomized phase II study has been initiated. 
P276-00 (Fig. 6) is a highly specific inhibitor of CDK2 $\left(\mathrm{IC}_{50}=10 \mathrm{nM}\right)$, which is much less selective toward CDK1 $\left(\mathrm{IC}_{50}=110 \mathrm{nM}\right)$ and $\mathrm{CDK} 4\left(\mathrm{IC}_{50}=130 \mathrm{nM}\right)$, with no significant activity toward 12 other kinases tested $\left(\mathrm{IC}_{50}=\right.$ $2 \mu \mathrm{M})$. It showed potent antiproliferative effects against various human cancer cell lines, such as MCF-7 and H-460 (Joshi et al. 2007). Several phase I/II clinical studies with P279-00 have been initiated, such as an open-label, multicenter phase I/II study of selective cyclin-dependent kinase inhibitor P276-00 in combination with radiation in subjects with recurrent and/or locally advanced squamous cell carcinoma of head and neck and a phase I/II study to evaluate safety and efficacy of P276-00 in combination with gemcitabine in patients with pancreatic cancer. The results of these studies are still in progress. Another phase I study in patients with refractory neoplasms was performed. Major DAEs were fatigue, hypotension, nausea, sweating and dry mouth. No responses were observed (Hirte et al. 2007).

\section{Conclusions}

The field of CDK inhibitor development had seen a significant enthusiasm and optimism in the past couple of decades. Recent developments in the small-molecule CDK inhibitor field led to several marketed products with a different spectrum of the inhibited targets. Actually, there are many more CDK inhibitors developed than are described in this review. Many more are still in development. These developments provided the investigators, interested in the role of CDKs in cancer or other cellular processes, with a whole panel of tools. The variety of these inhibitors allows us to choose the most effective and relevant approaches suited for the particular experiments. How to choose the appropriate inhibitor? First of all, most of the researchers would be limited by the availability of the compounds. However, there are quite a number of commercially inhibitors to choose from. Secondly, the investigator has to choose the specificity of the inhibitor, according to the CDK (or several CDKs) he would like to inhibit. Wishful thinking, like "roscovitine is selective CDK5 inhibitor", will certainly not help in this decision. Lastly, if working on a disease model, it would certainly help to consider using the inhibitors, which are already under the investigation in clinical trials. In some cases, if not most cases, the results obtained using CDK inhibitors should be validated using other techniques, such as siRNA,/micro-RNA knockdowns, dominant-negative CDKs or knockout mice.

The basic as well as preclinical cancer research is not the only fields, which can profit from the use of CDK inhibitors. They continue to hold much potential as new agents in the treatment of cancer. The crucial question that remains unanswered is which CDK or range of CDKs should be tar- geted. Studies with the inhibitors should determine whether highly selective or rather broad-range $\mathrm{CDK}$ inhibitors are more effective for anticancer therapy. The therapeutic significance of inhibiting particular CDKs is greatly dependent on the genetic background and the specific signaling pathways that direct proliferation of the tumor cells. Preclinical studies in suitable animal models ought to provide important information for the design of more clinical studies assessing improved efficacy of these agents. The results from clinical studies to date imply that monotherapy might not be the best application of CDK inhibitors. However, the results of these agents in combination with chemotherapy seem to be more optimistic. On the other hand, there is also the lack of clinically useful prognostic and predictive biomarkers that associate directly with CDK inhibition. In addition, new insights into CDK biology will provide innovative biomedical rationales for the therapeutic applications.

Conflict of interest Authors state no conflict of interests.

\section{References}

Aklilu M, Kindler HL, Donehower RC, Mani S, Vokes EE (2003) Phase II study of flavopiridol in patients with advanced colorectal cancer. Ann Oncol 14(8):1270-1273. doi:10.1093/annonc/ $\operatorname{mdg} 343$

Arguello F, Alexander M, Sterry JA, Tudor G, Smith EM, Kalavar NT, Greene JF Jr, Koss W, Morgan CD, Stinson SF, Siford TJ, Alvord WG, Klabansky RL, Sausville EA (1998) Flavopiridol induces apoptosis of normal lymphoid cells, causes immunosuppression, and has potent antitumor activity In vivo against human leukemia and lymphoma xenografts. Blood 91(7):2482-2490

Arris CE, Boyle FT, Calvert AH, Curtin NJ, Endicott JA, Garman EF, Gibson AE, Golding BT, Grant S, Griffin RJ, Jewsbury P, Johnson LN, Lawrie AM, Newell DR, Noble ME, Sausville EA, Schultz R, Yu W (2000) Identification of novel purine and pyrimidine cyclin-dependent kinase inhibitors with distinct molecular interactions and tumor cell growth inhibition profiles. J Med Chem 43(15):2797-2804. doi:10.1021/jm990628o

Benson C, White J, De Bono J, O'Donnell A, Raynaud F, Cruickshank C, McGrath H, Walton M, Workman P, Kaye S, Cassidy J, Gianella-Borradori A, Judson I, Twelves C (2007) A phase I trial of the selective oral cyclin-dependent kinase inhibitor seliciclib (CYC202; R-Roscovitine), administered twice daily for 7 days every 21 days. Br J Cancer 96(1):29-37. doi:10.1038/sj.bjc. 6603509

Bergqvist J, Elmberger G, Ohd J, Linderholm B, Bjohle J, Hellborg H, Nordgren H, Borg AL, Skoog L, Bergh J (2006) Activated ERK1/ 2 and phosphorylated oestrogen receptor alpha are associated with improved breast cancer survival in women treated with tamoxifen. Eur J Cancer 42(8):1104-1112. doi:10.1016/j.ejca. 2006.01.028

Berkofsky-Fessler W, Nguyen TQ, Delmar P, Molnos J, Kanwal C, DePinto W, Rosinski J, McLoughlin P, Ritland S, DeMario M, Tobon K, Reidhaar-Olson JF, Rueger R, Hilton H (2009) Preclinical biomarkers for a cyclin-dependent kinase inhibitor translate to candidate pharmacodynamic biomarkers in phase I patients. Mol Cancer Ther 8(9):2517-2525. doi:10.1158/1535-7163.MCT09-0083 
Bible KC, Lensing JL, Nelson SA, Lee YK, Reid JM, Ames MM, Isham CR, Piens J, Rubin SL, Rubin J, Kaufmann SH, Atherton PJ, Sloan JA, Daiss MK, Adjei AA, Erlichman C (2005) Phase 1 trial of flavopiridol combined with cisplatin or carboplatin in patients with advanced malignancies with the assessment of pharmacokinetic and pharmacodynamic end points. Clin Cancer Res 11(16):5935-5941. doi:10.1158/1078-0432.CCR-04-2566

Blum W, Phelps MA, Klisovic RB, Rozewski DM, Ni W, Albanese KA, Rovin B, Kefauver C, Devine SM, Lucas DM, Johnson A, Schaaf LJ, Byrd JC, Marcucci G, Grever MR (2010) Phase I clinical and pharmacokinetic study of a novel schedule of flavopiridol in relapsed or refractory acute leukemias. Haematologica 95(7):1098-1105. doi:10.3324/haematol.2009.017103

Burdette-Radoux S, Tozer RG, Lohmann RC, Quirt I, Ernst DS, Walsh W, Wainman N, Colevas AD, Eisenhauer EA (2004) Phase II trial of flavopiridol, a cyclin dependent kinase inhibitor, in untreated metastatic malignant melanoma. Invest New Drugs 22(3):315322. doi:10.1023/B:DRUG.0000026258.02846.1c

Carlson BA, Dubay MM, Sausville EA, Brizuela L, Worland PJ (1996) Flavopiridol induces G1 arrest with inhibition of cyclin-dependent kinase (CDK) 2 and CDK4 in human breast carcinoma cells. Cancer Res 56(13):2973-2978

Carvajal RD, Tse A, Shah MA, Lefkowitz RA, Gonen M, Gilman-Rosen L, Kortmansky J, Kelsen DP, Schwartz GK, O'Reilly EM (2009) A phase II study of flavopiridol (Alvocidib) in combination with docetaxel in refractory, metastatic pancreatic cancer. Pancreatology 9(4):404-409. doi:10.1159/000187135

Choi HS, Lee Y, Park KH, Sung JS, Lee JE, Shin ES, Ryu JS, Kim YH (2009) Single-nucleotide polymorphisms in the promoter of the CDK5 gene and lung cancer risk in a Korean population. J Hum Genet 54(5):298-303. doi:10.1038/jhg.2009.29

Cicenas J (2007) The potential role of EGFR/ErbB2 heterodimer in breast cancer. Expert opinion Ther Patents 17(6):607-616. doi: $10.1517 / 13543776.17 .6 .607$

Cicenas J (2008) The potential role of Akt phosphorylation in human cancers. Int J Bio Markers 23(1):1-9

Cicenas J, Kueng W, Wight E, Eppenberger-Castori S, Eppenberger U (2004) Prognostic value of phosphorylated Akt in primary breast cancer. [abstract]. In: Proceedings of the 95th annual meeting of the American Association for Cancer Research; 2004 March 2731; Orlando, FL: AACR; 2004. http://aacrmeetingabstracts.org/ cgi/content/abstract/2004/1/813-c

Cicenas J, Urban P, Vuaroqueaux V, Labuhn M, Küng W, Wight E, Mayhew M, Eppenberger U, Eppenberger-Castori S (2005) Increased level of phosphorylated akt measured by chemiluminescence-linked immunosorbent assay is a predictor of poor prognosis in primary breast cancer overexpressing ErbB-2. Breast Cancer Res 7(4):R394-R401. doi:10.1186/bcr1015

Cicenas J, Urban P, Küng W, Vuaroqueaux V, Labuhn M, Wight E, Eppenberger U, Eppenberger-Castori S (2006) Phosphorylation of tyrosine 1248-ERBB2 measured by chemiluminescence-linked immunoassay is an independent predictor of poor prognosis in primary breast cancer patients. Eur J Cancer 42(5):636-645. doi:10.1016/j.ejca.2005.11.012

Cicenas J, Küng W, Eppenberger U, Eppenberger-Castori S (2010) Increased level of phosphorylated ShcA measured by chemiluminescence-linked immunoassay is a predictor of good prognosis in primary breast cancer expressing low levels of estrogen receptor. Cancers 2(1):153-164. doi:10.3390/cancers2010153

Clarke RB (2003) p27KIP1 phosphorylation by PKB/Akt leads to poor breast cancer prognosis. Breast Cancer Res 5(3):162-163. doi: $10.1186 /$ bcr596

Derenzini M, Montanaro L, Vici M, Barbieri S, Ceccarelli C, Santini D, Taffurelli M, Martinelli GN, Treré D (2007) Relationship between the RB1 mRNA level and the expression of phosphorylated RB protein in human breast cancers: their relevance in cell proliferation activity and patient clinical outcome. Histol Histopathol 22(5):505-513

Dhariwala FA, Rajadhyaksha MS (2008) An unusual member of the Cdk family: Cdk5. Cell Mol Neurobiol 28(3):351-369. doi:10.1007/s10571-007-9242-1

Dickson MA, Rathkopf DE, Carvajal RD, Grant S, Roberts JD, Reid JM, Ames MM, McGovern RM, Lefkowitz RA, Gonen M, Cane LM, Dials HJ, Schwartz GK (2010) A phase I pharmacokinetic study of pulse-dose vorinostat with flavopiridol in solid tumors. Invest New Drugs May 12. [Epub ahead of print]. doi:10.1007/ s10637-010-9447-x

DiGiovanna MP, Stern DF, Edgerton SM, Whalen SG, Moore D 2nd, Thor AD (2005) Relationship of epidermal growth factor receptor expression to ErbB-2 signaling activity and prognosis in breast cancer patients. J Clin Oncol 23(6):1152-1160. doi:10.1200/ JCO.2005.09.055

Drees M, Dengler WA, Roth T, Labonte H, Mayo J, Malspeis L, Grever M, Sausville EA, Fiebig HH (1997) Flavopiridol (L868275): selective antitumor activity in vitro and activity in vivo for prostate carcinoma cells. Clin Cancer Res 3(2):273-279

Duan Y, He X, Yang H, Ji Y, Tao T, Chen J, Hu L, Zhang F, Li X, Wang H, Shen A, Lu X (2010) Cyclin D3/CDK11(p58) complex involved in Schwann cells proliferation repression caused by lipopolysaccharide. Inflammation 33(3):189-199. doi:10.1007/ s10753-009-9173-8

El-Rayes BF, Gadgeel S, Parchment R, Lorusso P, Philip PA (2006) A phase I study of flavopiridol and docetaxel. Invest New Drugs 24(4):305-310. doi:10.1007/s10637-005-4343-5

Fekrazad HM, Verschraegen CF, Royce M, Smith HO, Chyi Lee F, Rabinowitz I (2010) A phase I study of flavopiridol in combination with gemcitabine and irinotecan in patients with metastatic cancer. Am J Clin Oncol 33(4):393-397. doi:10.1097/COC. 0b013e3181b2043f

Fischer PM, Gianella-Borradori A (2005) Recent progress in the discovery and development of cyclin-dependent kinase inhibitors. Expert Opin Investig Drugs 14(4):457-477. doi:10.1517/ 13543784.14.4.457

Fisher RP (2005) Secrets of a double agent: CDK7 in cell-cycle control and transcription. J Cell Sci 118(Pt 22):5171-5180. doi:10.1242/ jcs. 02718

Fornier MN, Rathkopf D, Shah M, Patil S, O'Reilly E, Tse AN, Hudis C, Lefkowitz R, Kelsen DP, Schwartz GK (2007) Phase I dose-finding study of weekly docetaxel followed by flavopiridol for patients with advanced solid tumors. Clin Cancer Res 13(19):5841-5846. doi:10.1158/1078-0432.CCR07-1218

Fry DW, Harvey PJ, Keller PR, Elliott WL, Meade M, Trachet E, Albassam M, Zheng X, Leopold WR, Pryer NK, Toogood PL (2004) Specific inhibition of cyclin-dependent kinase 4/6 by PD 0332991 and associated antitumor activity in human tumor xenografts. Mol Cancer Ther 3(11):1427-1438

George S, Kasimis BS, Cogswell J, Schwarzenberger P, Shapiro GI, Fidias P, Bukowski RM (2008) Phase I study of flavopiridol in combination with Paclitaxel and Carboplatin in patients with nonsmall-cell lung cancer. Clin Lung Cancer 9(3):160-165. doi:10.3816/ CLC.2008.n.024

Grendys EC Jr, Blessing JA, Burger R, Hoffman J (2005) A phase II evaluation of flavopiridol as second-line chemotherapy of endometrial carcinoma: a Gynecologic Oncology Group study. Gynecol Oncol 98(2):249-253. doi:10.1016/j.ygyno.2005.05.017

Hansel DE, Dhara S, Huang RC, Ashfaq R, Deasel M, Shimada Y, Bernstein HS, Harmon J, Brock M, Forastiere A, Washington MK, Maitra A, Montgomery E (2005) CDC2/CDK1 expression in esophageal adenocarcinoma and precursor lesions serves as a diagnostic and cancer progression marker and potential novel drug target. Am J Surg Pathol 29(3):390-399 
Heath EI, Bible K, Martell RE, Adelman DC, Lorusso PM (2008) A phase 1 study of SNS-032 (formerly BMS-387032), a potent inhibitor of cyclin-dependent kinases 2, 7 and 9 administered as a single oral dose and weekly infusion in patients with metastatic refractory solid tumors. Invest New Drugs 26(1):59-65. doi:10.1007/s10637-007-9090-3

Helal CJ, Sanner MA, Cooper CB, Gant T, Adam M, Lucas JC, Kang Z, Kupchinsky S, Ahlijanian MK, Tate B, Menniti FS, Kelly K, Peterson M (2004) Discovery and SAR of 2-aminothiazole inhibitors of cyclin-dependent kinase $5 / \mathrm{p} 25$ as a potential treatment for Alzheimer's disease. Bioorg Med Chem Lett 14(22):5521-5525. doi:10.1016/j.bmcl.2004.09.006

Hirte HW, Raghunadharao D, Baetz T, Hotte S, Rajappa S, Iacobucci A, Sharma S, Parikh H, Kulkarni S, Patil S, Gaston S (2007) A phase 1 study of the selective cyclin dependent kinase inhibitor P276-00 in patients with advanced refractory neoplasms. J Clinical Oncol, ASCO Annual meeting proceedings part I. 25(18S) (June 20 Supplement):14117. http://meeting.ascopubs.org/cgi/content/abstract/25/18_suppl/14117

Hunter T, Cooper JA (1985) Protein-tyrosine kinases. Annu Rev Biochem 54:897-930. doi:10.1146/annurev.bi.54.070185.004341

Jeon S, Choi JY, Lee KM, Park SK, Yoo KY, Noh DY, Ahn SH, Kang D (2010) Combined genetic effect of CDK7 and ESR1 polymorphisms on breast cancer. Breast Cancer Res Treat 121(3):737742. doi:10.1007/s10549-009-0640-6

Joshi KS, Rathos MJ, Joshi RD, Sivakumar M, Mascarenhas M, Kamble S, Lal B, Sharma S (2007) In vitro antitumor properties of a novel cyclin-dependent kinase inhibitor, P276-00. Mol Cancer Ther 6(3):918-925. doi:10.1158/1535-7163.MCT-06-0613

Kanematsu T, Yano S, Uehara H, Bando Y, Sone S (2003) Phosphorylation, but not overexpression, of epidermal growth factor receptor is associated with poor prognosis of non-small cell lung cancer patients. Oncol Res 13(5):289-298

Karp JE, Passaniti A, Gojo I, Kaufmann S, Bible K, Garimella TS, Greer J, Briel J, Smith BD, Gore SD, Tidwell ML, Ross DD, Wright JJ, Colevas AD, Bauer KS (2005) Phase I and pharmacokinetic study of flavopiridol followed by 1-beta-D-arabinofuranosylcytosine and mitoxantrone in relapsed and refractory adult acute leukemias. Clin Cancer Res 11(23):8403-8412. doi:10.1158/1078-0432.CCR-05-1201

Karp JE, Smith BD, Resar LS, Greer JM, Blackford A, Zhao M, Moton-Nelson D, Alino K, Levis MJ, Gore SD, Joseph B, Carraway H, McDevitt MA, Bagain L, Mackey K, Briel J, Doyle LA, Wright JJ, Rudek MA (2011) Phase I and pharmacokinetic study of bolus-infusion flavopiridol followed by cytosine arabinoside and mitoxantrone for acute leukemias. Blood 117(12):33023310. doi:10.1182/blood-2010-09-310862

Kasten M, Giordano A (2001) Cdk10, a Cdc2-related kinase, associates with the Ets 2 transcription factor and modulates its transactivation activity. Oncogene 20(15):1832-1838

Kaur G, Stetler-Stevenson M, Sebers S, Worland P, Sedlacek H, Myers C, Czech J, Naik R, Sausville E (1992) Growth inhibition with reversible cell cycle arrest of carcinoma cells by flavone L868275. J Natl Cancer Inst 84(22):1736-1740. doi:10.1093/jnci/ 84.22.1736

Kim SJ, Nakayama S, Miyoshi Y, Taguchi T, Tamaki Y, Matsushima T, Torikoshi Y, Tanaka S, Yoshida T, Ishihara H, Noguchi S (2008) Determination of the specific activity of CDK1 and CDK2 as a novel prognostic indicator for early breast cancer. Ann Oncol 19(1):68-72. doi:10.1093/annonc/mdm358

Kouroukis CT, Belch A, Crump M, Eisenhauer E, Gascoyne RD, Meyer R, Lohmann R, Lopez P, Powers J, Turner R, Connors JM, National Cancer Institute of Canada Clinical Trials Group (2003) Flavopiridol in untreated or relapsed mantle-cell lymphoma: results of a phase II study of the National Cancer Institute of Canada. Clinical Trials Group. J Clin Oncol 21(9):1740-1745
Kusume T, Tsuda H, Kawabata M, Inoue T, Umesaki N, Suzuki T, Yamamoto K (1999) The p16-cyclin D1/CDK4-pRb pathway and clinical outcome in epithelial ovarian cancer. Clin Cancer Res 5(12):4152-4157

Lane ME, Yu B, Rice A, Lipson KE, Liang C, Sun L, Tang C, McMahon G, Pestell RG, Wadler S (2001) A novel cdk2-selective inhibitor, SU9516, induces apoptosis in colon carcinoma cells. Cancer Res 61(16):6170-6177

Le Tourneau C, Faivre S, Laurence V, Delbaldo C, Vera K, Girre V, Chiao J, Armour S, Frame S, Green SR, Gianella-Borradori A Diéras V, Raymond E (2010) Phase I evaluation of seliciclib (R-roscovitine), a novel oral cyclin-dependent kinase inhibitor, in patients with advanced malignancies. Eur J Cancer 46(18):32433250. doi:10.1016/j.ejca.2010.08.001

Lin TS, Ruppert AS, Johnson AJ, Fischer B, Heerema NA, Andritsos LA, Blum KA, Flynn JM, Jones JA, Hu W, Moran ME, Mitchell SM, Smith LL, Wagner AJ, Raymond CA, Schaaf LJ, Phelps MA, Villalona-Calero MA, Grever MR, Byrd JC (2009) Phase II study of flavopiridol in relapsed chronic lymphocytic leukemia demonstrating high response rates in genetically high-risk disease. J Clin Oncol 27(35):6012-6018. doi:10.1200/JCO.2009.22.694470

Liu G, Gandara DR, Lara PN Jr, Raghavan D, Doroshow JH, Twardowski P, Kantoff P, Oh W, Kim K, Wilding G (2004) A Phase II trial of flavopiridol (NSC \#649890) in patients with previously untreated metastatic androgen-independent prostate cancer. Clin Cancer Res 10(3):924-928. doi:10.1158/10780432.CCR-03-0050

Liu JL, Wang XY, Huang BX, Zhu F, Zhang RG, Wu G (2010) Expression of CDK5/p35 in resected patients with non-small cell lung cancer: relation to prognosis. Med Oncol. Mar 31. [Epub ahead of print]. doi:10.1007/s12032-010-9510-7

Losiewicz MD, Carlson BA, Kaur G, Sausville EA, Worland PJ (1994) Potent inhibition of CDC2 kinase activity by the flavonoid L868275. Biochem Biophys Res Commun 201(2):589-595. doi: $10.1006 /$ bbrc. 1994.1742

Loyer P, Trembley JH, Grenet JA, Busson A, Corlu A, Zhao W, Kocak M, Kidd VJ, Lahti JM (2008) Characterization of cyclin L1 and L2 interactions with CDK11 and splicing factors: influence of cyclin L isoforms on splice site selection. J Biol Chem 283(12):7721-7732. doi:10.1074/jbc.M708188200

Mahadevan D, Plummer R, Squires MS, Rensvold D, Kurtin S, Pretzinger C, Dragovich T, Adams J, Lock V, Smith DM, Von Hoff D, Calvert H (2011) A phase I pharmacokinetic and pharmacodynamic study of AT7519, a cyclin-dependent kinase inhibitor in patients with refractory solid tumors. Ann Oncol. Feb 16 [Epub ahead of print]. doi:10.1093/annonc/mdq734

Malumbres M, Barbacid M (2005) Mammalian cyclin-dependent kinases. Trends Biochem Sci 30(11):630-641. doi:10.1016/ j.tibs.2005.09.005

Malumbres M, Harlow E, Hunt T, Hunter T, Lahti JM, Manning G, Morgan DO, Tsai LH, Wolgemuth DJ (2009) Cyclin-dependent kinases: a family portrait. Nat Cell Biol 11(11):1275-1276. doi:10.1038/ncb1109-1275

Marone M, Scambia G, Giannitelli C, Ferrandina G, Masciullo V, Bellacosa A, Benedetti-Panici P, Mancuso S (1998) Analysis of cyclin $\mathrm{E}$ and $\mathrm{CDK} 2$ in ovarian cancer: gene amplification and RNA overexpression. Int J Cancer 75(1):34-39. doi:10.1002/(SICI) 1097-0215(19980105)75:1<34::AID-IJC6>3.0.CO;2-2

Mihara M, Shintani S, Nakahara Y, Kiyota A, Ueyama Y, Matsumura T, Wong DT (2001) Overexpression of CDK2 is a prognostic indicator of oral cancer progression. Jpn J Cancer Res 92(3):352-360

Milde-Langosch K, Bamberger AM, Rieck G, Grund D, Hemminger G, Müller V, Löning T (2005) Expression and prognostic relevance of activated extracellular-regulated kinases (ERK1/2) in breast cancer. Br J Cancer 92(12):2206-2215. doi:10.1038/ sj.bjc. 6602655 
Morris DG, Bramwell VH, Turcotte R, Figueredo AT, Blackstein ME, Verma S, Matthews S, Eisenhauer EA (2006) A phase II study of flavopiridol in patients with previously untreated advanced soft tissue sarcoma. Sarcoma 2006:64374. doi:10.1155/SRCM/2006/ 64374

Nakayama S, Torikoshi Y, Takahashi T, Yoshida T, Sudo T, Matsushima T, Kawasaki Y, Katayama A, Gohda K, Hortobagyi GN, Noguchi S, Sakai T, Ishihara H, Ueno NT (2009) Prediction of paclitaxel sensitivity by CDK1 and CDK2 activity in human breast cancer cells. Breast Cancer Res 11(1):R12. doi:10.1186/ bcr2231

Niesvizky R, Lentzsch S, Badros AZ, Chanan-Khan AA, Singhal SB, Zonder JA, Vij R, Huang X, DiLiberto M, Courtney R, Shaik MN, Kim ST, Randolph S, Ely SA, Chen-Kiang S (2010) A phase I study of PD 0332991: complete CDK4/6 inhibition and tumor response in sequential combination with bortezomib and dexamethasone for relapsed and refractory multiple myeloma. Oral session: myeloma—therapy, excluding transplantation: myeloma phase I/II trials and correlative studies. http://ash.confex.com/ash/ 2010/webprogram/Paper26540.html

Patel V, Senderowicz AM, Pinto D Jr, Igishi T, Raffeld M, QuintanillaMartinez L, Ensley JF, Sausville EA, Gutkind JS (1998) Flavopiridol, a novel cyclin-dependent kinase inhibitor, suppresses the growth of head and neck squamous cell carcinomas by inducing apoptosis. J Clin Invest 102(9):1674-1681. doi:10.1172/JCI3661

Phelps MA, Lin TS, Johnson AJ, Hurh E, Rozewski DM, Farley KL, Wu D, Blum KA, Fischer B, Mitchell SM, Moran ME, BrookerMcEldowney M, Heerema NA, Jarjoura D, Schaaf LJ, Byrd JC, Grever MR, Dalton JT (2009) Clinical response and pharmacokinetics from a phase 1 study of an active dosing schedule of flavopiridol in relapsed chronic lymphocytic leukemia. Blood 113(12):2637-2645. doi:10.1182/blood-2008-07-168583

Poomsawat S, Buajeeb W, Khovidhunkit SO, Punyasingh J (2010) Alteration in the expression of cdk4 and cdk6 proteins in oral cancer and premalignant lesions. J Oral Pathol Med 39(10):793-799. doi:10.1111/j.1600-0714.2010.00909.x

Rathkopf D, Dickson MA, Feldman DR, Carvajal RD, Shah MA, Wu N, Lefkowitz R, Gonen M, Cane LM, Dials HJ, Winkelmann JL, Bosl GJ, Schwartz GK (2009) Phase I study of flavopiridol with oxaliplatin and fluorouracil/leucovorin in advanced solid tumors. Clin Cancer Res 15(23):7405-7411. doi:10.1158/1078-0432.CCR09-1502

Roll DM, Ireland CM, Lu HSM, Clardy J (1988) Fascaplysin, an unusual antimicrobial pigment from the marine sponge Fascaplysinopsis sp. J Org Chem 53(14):3276-3278. doi:10.1021/jo00249a025

Ryu CK, Kang HY, Lee SK, Nam KA, Hong CY, Ko WG, Lee BH (2000) 5-Arylamino-2-methyl-4, 7-dioxobenzothiazoles as inhibitors of cyclin-dependent kinase 4 and cytotoxic agents. Bioorg Med Chem Lett 10(5):461-464. doi:10.1016/S0960-894X(00) 00014-7

Schwartz GK, Ilson D, Saltz L, O'Reilly E, Tong W, Maslak P, Werner J, Perkins P, Stoltz M, Kelsen D (2001) Phase II study of the cyclindependent kinase inhibitor flavopiridol administered to patients with advanced gastric carcinoma. J Clin Oncol 19(7):1985-1992

Schwartz GK, O'Reilly E, Ilson D, Saltz L, Sharma S, Tong W, Maslak P, Stoltz M, Eden L, Perkins P, Endres S, Barazzoul J, Spriggs D, Kelsen D (2002) Phase I study of the cyclin-dependent kinase inhibitor flavopiridol in combination with paclitaxel in patients with advanced solid tumors. J Clin Oncol 20(8):2157-2170. doi:10.1200/JCO.2004.01.0660

Semczuk A, Miturski R, Skomra D, Jakowicki JA (2004) Expression of the cell-cycle regulatory proteins ( $\mathrm{pRb}$, cyclin D1, p16INK4A and cdk4) in human endometrial cancer: correlation with clinicopathological features. Arch Gynecol Obstet 269(2):104-110. doi:10.1007/s00404-002-0449-6
Senderowicz AM, Headlee D, Stinson SF, Lush RM, Kalil N, Villalba L, Hill K, Steinberg SM, Figg WD, Tompkins A, Arbuck SG, Sausville EA (1998) Phase I trial of continuous infusion flavopiridol, a novel cyclin-dependent kinase inhibitor, in patients with refractory neoplasms. J Clin Oncol 16(9):2986-2999

Shah MA, Kortmansky J, Motwani M, Drobnjak M, Gonen M, Yi S, Weyerbacher A, Cordon-Cardo C, Lefkowitz R, Brenner B, O'Reilly E, Saltz L, Tong W, Kelsen DP, Schwartz GK (2005) A phase I clinical trial of the sequential combination of irinotecan followed by flavopiridol. Clin Cancer Res 11(10):3836-3845. doi:10.1158/1078-0432.CCR-04-2651

Shapiro GI, Supko JG, Patterson A, Lynch C, Lucca J, Zacarola PF, Muzikansky A, Wright JJ, Lynch TJ Jr, Rollins BJ (2001) A phase II trial of the cyclin-dependent kinase inhibitor flavopiridol in patients with previously untreated stage IV non-small cell lung cancer. Clin Cancer Res 7(6):1590-1599

Simon R, Struckmann K, Schraml P, Wagner U, Forster T, Moch H, Fijan A, Bruderer J, Wilber K, Mihatsch MJ, Gasser T, Sauter G (2002) Amplification pattern of 12q13-q15 genes (MDM2, CDK4, GLI) in urinary bladder cancer. Oncogene 21(16):24762483. doi:10.1038/sj/onc/1205304

Slamon DJ, Hurvitz SA, Applebaum S, Glaspy JA, Allison MK, DiCarlo BA, Courtney RD, Kim ST, Randolph S, Finn S (2010) Phase I study of PD 0332991, cyclin-D kinase (CDK) 4/6 inhibitor in combination with letrozole for first-line treatment of patients with ER-positive, HER2-negative breast cancer. J Clinical Oncol, 2010 ASCO annual meeting proceedings (Post-meeting edition). 28(15) (May 20 Supplement):3060

Svensson S, Jirström K, Rydén L, Roos G, Emdin S, Ostrowski MC, Landberg G (2005) ERK phosphorylation is linked to VEGFR2 expression and Ets-2 phosphorylation in breast cancer and is associated with tamoxifen treatment resistance and small tumors with good prognosis. Oncogene 24(27):4370-4379. doi:10.1038/ sj.onc. 1208626

Tan AR, Headlee D, Messmann R, Sausville EA, Arbuck SG, Murgo AJ, Melillo G, Zhai S, Figg WD, Swain SM, Senderowicz AM (2002) Phase I clinical and pharmacokinetic study of flavopiridol administered as a daily 1-hour infusion in patients with advanced neoplasms. J Clin Oncol 20(19):4074-4082. doi:10.1200/ JCO.2002.01.043

Tan AR, Yang X, Berman A, Zhai S, Sparreboom A, Parr AL, Chow C, Brahim JS, Steinberg SM, Figg WD, Swain SM (2004) Phase I trial of the cyclin-dependent kinase inhibitor flavopiridol in combination with docetaxel in patients with metastatic breast cancer. Clin Cancer Res 10(15):5038-5047. doi:10.1158/10780432.CCR-04-0025

Thomas JP, Tutsch KD, Cleary JF, Bailey HH, Arzoomanian R, Alberti D, Simon K, Feierabend C, Binger K, Marnocha R, Dresen A, Wilding G (2002) Phase I clinical and pharmacokinetic trial of the cyclin-dependent kinase inhibitor flavopiridol. Cancer Chemother Pharmacol 50(6):465-472. doi:10.1007/s00280-002-0527-2

Tong WG, Chen R, Plunkett W, Siegel D, Sinha R, Harvey RD, Badros AZ, Popplewell L, Coutre S, Fox JA, Mahadocon K, Chen T, Kegley P, Hoch U, Wierda WG (2010) Phase I and pharmacologic study of SNS-032, a potent and selective Cdk2, 7, and 9 inhibitor, in patients with advanced chronic lymphocytic leukemia and multiple myeloma. J Clin Oncol 28(18):3015-3022. doi:10.1200/JCO.2009.26.1347

Van Veldhuizen PJ, Faulkner JR, Lara PN Jr, Gumerlock PH, Goodwin JW, Dakhil SR, Gross HM, Flanigan RC, Crawford ED, Southwest Oncology Group (2005) A phase II study of flavopiridol in patients with advanced renal cell carcinoma: results of Southwest Oncology Group Trial 0109. Cancer Chemother Pharmacol 56(1):39-45. doi:10.1007/s00280-004-0969-9 
Villerbu N, Gaben AM, Redeuilh G, Mester J (2002) Cellular effects of purvalanol A: a specific inhibitor of cyclin-dependent kinase activities. Int J Cancer 97(6):761-769. doi:10.1002/ijc.10125

Whitlock JA, Krailo M, Reid JM, Ruben SL, Ames MM, Owen W, Reaman G (2005) Children's oncology group study. Phase I clinical and pharmacokinetic study of flavopiridol in children with refractory solid tumors: a Children's Oncology Group Study. J Clin Oncol 23(36):9179-9186. doi:10.1200/JCO.2004.01.0660
Xia W, Chen JS, Zhou X, Sun PR, Lee DF, Liao Y, Zhou BP, Hung MC (2004) Phosphorylation/cytoplasmic localization of p21Cip1/WAF1 is associated with HER2/neu overexpression and provides a novel combination predictor for poor prognosis in breast cancer patients. Clin Cancer Res 10(11):3815-3824. doi:10.1158/1078-0432.CCR-03-0527 